\title{
Evolution and perspectives of agrarian export of Ukraine
}

\section{Dukhnytskyi B.}

NSC «Institute of agrarian economy», Heroiv Oborony Str., 10, Kyiv, 03127, Ukraine; e-mail: duhnitsky@faust.kiev.ua

The purpose. To study in dynamics key indexes of export by Ukraine of agricultural products, to characterize its modern lines and to evaluate opportunities for the further growth in short-term perspective. Methods. Theoretical generalization, analysis and synthesis, relative evaluation, graphical and table. Results. Actual state of export of agricultural products of Ukraine in view of its specific features is analyzed. List of regions and countries where domestic agricultural products uses the greatest demand is brought. Special attention is paid to strong and weak sides in commodity structure of our agricultural export. Quantitative and cost standard items of products of Ukraine abroad in a slit of all key commodity positions are considered. Rating positions of our state in the world markets of the selected agrarian products are specified. Recommendations on directions of improvement of export are given and assessment of objective opportunities of domestic agrarian branch in immediate prospects is realized. Conclusions. Agricultural export of Ukraine has precisely delineated commodity structure and the basic commodity markets. Deciding influence on its operation is carried out through liberalization of trade within the limits of World trading organization and Agreement on association with the European Union. In last three years it is observed increase of its cost indexes, and the share of products of agrarian and industrial complex in total export of Ukraine is very high. Thus there is not used a lot of opportunities which are capable to open new trading associates for our farmers, to lower existing dependence on price vacillating and to diversify assortment of offered products. Implementation of conforming actions descends constantly, however slowly enough. Therefore, at absence of serious vacillating in economic, political and social status, most likely, existing trends in agrarian export of Ukraine will remain determining.

Key words: agriculture, agrarian products, export, commodity framework, global market, perspective.

DOI: https://doi.org/10.31073/agrovisnyk201905-09

The potential of agricultural sector in any state is not only an objective opportunity to satisfy the needs of domestic market by production, but also the competitiveness of its products abroad on a global scale [1]. Our country confidently holds its position in the world agricultural market, acting as a stable and well-known supplier of food. In the global ranking of agricultural exporters Ukraine is in the middle between 20-th and 30th positions. In a large measure, this became possible as a result of accession to the World Trade Organization and signing the Association Agreement with the European Union [2]. Despite this, the potential of agricultural exports can not be fully exploited due to specific features of the domestic industry and constant changes in the global market situation.

Issues of the current state, characteristic tendencies and opportunities for increasing agro-food exports of Ukraine are considered in the publication of Ukrainian scientists, in particular Yu.O. Lupenko [3], M.I. Pugachov [3, 5, 7, 10], S.M. Kvasha [4, 9], P.T. Sabluk [8], V.I. Vlasov [4, 8], as well as statistical and analytical materials of national and international professional institutions.

The purpose of the research is to analyze the general characteristics, commodity and geographical structure of Ukrainian agricultural export, as well as to determine the most likely scenario of its development in the coming years.

Research methods. In research process the following methods were used: theoretical generalization - to determine the importance of domestic agricultural production in the context of meeting consumer needs on national and global food markets, analysis and synthesis - to detail commodity structure of agricultural export and the impact of significant changes in terms of trade over the last decade for Ukraine on formation the agrarian factor of currency earnings, comparative estimation - to specify the position of our country in 
global markets of certain agricultural products, graphic and tabular - for the visual displaying statistical results of scientific research.

Research results. Although the overall dynamics of exports agricultural products in Ukraine (commodity groups 1-24 HS) is characterized by a tendency of growth, there were also periods of decline, the minimums of which were the last in 2015-2016, reflecting the negative situation almost in all areas of national strategic importance spheres (Fig. 1).

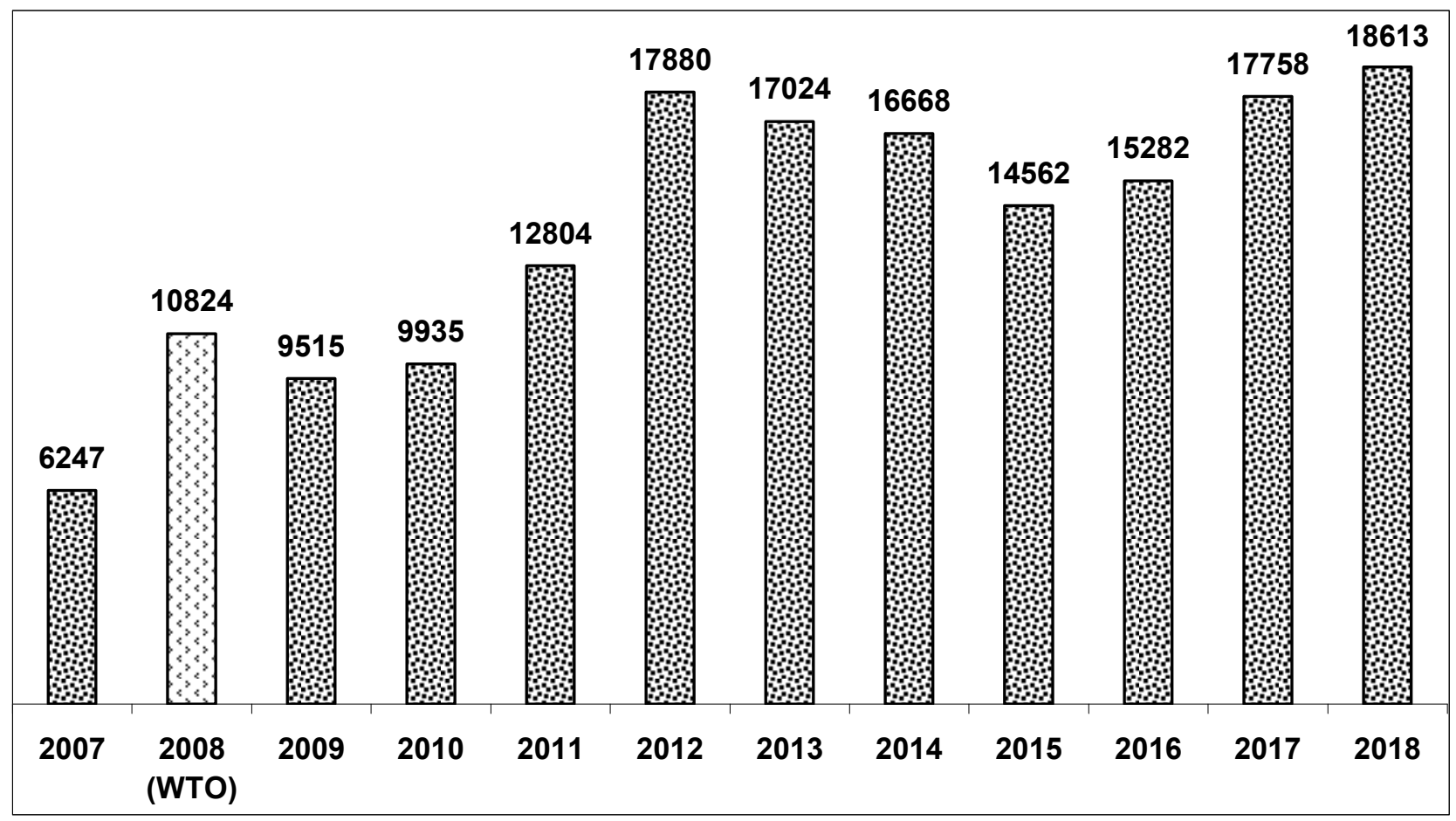

Fig. 1. Export of agrarian products by Ukraine, USD mIn.

For a long time, according to the State Statistics Service, record value for the domestic agricultural export remained at the level of 17.9 billion dollars in 2012, which wasn't quickly exceeded even after signing the Association Agreement. However, the continued liberalization of trade conditions finally led to a gradual increase in export supplies and a new record of $\$ 18.6$ billion according to the results of 2018. Thus, a positive balance of our agrarian trade reached over 13.5 billion dollars, and agricultural production took almost $40 \%$ of Ukraine's total exports.

The basis of domestic agricultural exports is formed by raw materials of plant origin, and ready food products account for less than $20 \%$ in its commodity structure $[3,4,5]$. Last year this tendency was confirmed again, because in general vegetal products took over half of the domestic exports of agroindustrial complex, and cereals, vegetable oil, oilseeds, wastes and meat products together formed more than $4 / 5$ of external supplies. Although livestock production is usually less than other combined groups, it has been possible to substantially increase, especially in 2017-2018, by export of poultry meat, which made it one of the most profitable agrarian commodities. This happened not only because of quantitative growth of volumes, but also as a result of increasing prices for Ukrainian chicken meat during the specified period.

A distinctive feature of Ukrainian agro-industrial exports, including in 2018, is a clearly traceable targeting on four geographic regions: Asian countries -8.0 billion dollars $(42.6 \%$ of the total value), the European Union -6.3 billion dollars (33.5\%), Africa -2.3 billion dollars (12.2\%) and CIS countries -1.5 billion dollars $(8.0 \%)$. Thus, they accounted for more than $96 \%$ of foreign supplies agrarian products of Ukrainian production. Our country managed to increase the value export of agricultural goods to all of these regions, except Africa. Interestingly, in 2018, Ukraine also updated historically the largest export figures to the European Union and Asia, which became crucial for the overall increase in exports of agricultural products. The main buyers of our agrarian products in the last year were: India (\$1856 million), China (1172), the Netherlands (1162), Spain (1042), Egypt (889), Turkey (801), Italy (738), Germany (667), Poland (657) and 
Saudi Arabia ( $\$ 589$ million). These ten countries have generated just over $50 \%$ of revenues for domestic exporters.

According to the results of last year, Ukraine managed to establish many export records in foreign trade, in particular, the largest historically were exports of maize (21.4 million tons) and rapeseed (over 2.4 million tons). The absolute record achieved in the export of other agricultural products, in particular potatoes (22 thousand tons), frozen fruits and berries (48 thousand tons), malt (143 thousand tons), soybean oil (215 thousand tons), canned tomatoes (56 thousand tons), poultry meat (329 thousand tons), eggs (115 thousand tons), unconcentrated milk and cream without sugar (21 thousand tons).

If we consider the export of key commodity items in more detail, in 2018 Ukraine sold 41.7 million tons of cereals on foreign markets. In addition to record volumes of maize, it could be noted the supply of wheat (16.4 million tons) and barley (3.6 million tons). Despite the fact that this result was not the maximum, export value of Ukrainian cereals (USD 7.2 billion) became the highest for Ukraine, primarily due to an increase in export prices. It should be noted that the prices on which our country sold grain in the dynamics of the last ten years has been seriously fluctuating, so the growth of quantitative indicators of exports has not always been proportional to income. Grain crops in the past year had a wide geographical diversification of sales, mainly to Asia, Europe and Africa, where their main consumers were Egypt (9.2\% of the value), Spain (8.9\%), the Netherlands (7.7\%), China (7.6\%), Indonesia (6.7\%), Saudi Arabia (6.2\%). Together with Italy, the Philippines, Tunisia, Morocco and Libya, these states formed 2/3 purchases of grain crops.

Export volume of oilseeds was 4.8 million tons, and its value -1.9 billion dollars. The largest demand abroad among the crops of this group was rapeseed $\quad$ ( 1.0 billion) and soybeans ( $\$ 0.8$ billion), produced in Ukraine. These products were exported in 2018 mainly to Germany (17.6\%), Turkey (16.5\%), Belgium $(14.9 \%)$, France $(6.7 \%)$, Belarus $(6.6 \%)$ and the Netherlands $(5.2 \%)$. Considerable sales took place to Poland, Iran and Italy, and in aggregate all listed countries provided for Ukraine more than $78 \%$ of foreign currency earnings.

The products of the vegetable oil-extracting industry in export is almost entirely represented by sunflower oil, which was sold abroad 5.6 million tons last year on the amount of 4.1 billion dollars. Almost $40 \%$ of the goods in this group were purchased by India. At the same time, other notable buying countries did not even exceed this share: China $-9.5 \%$, Iraq $-5.8 \%$, the Netherlands $-5.7 \%$, Spain and Italy $(5.3 \%)$. Thus, six countries in the Ukrainian export of oils and fats took over $71 \%$ of its value.

Because of chicken meat, the export of which brought for our producers over 500 million dollars revenues, total sales of meat with offal products amounted to 646 million dollars. The main consumers of these products were countries from the European Union, the Middle East and the CIS, in particular the Netherlands (17.9\%), Slovakia (9.3\%), Saudi Arabia (9.0\%), Belarus (8.4\%), Iraq (7.0\%), Azerbaijan (6.1\%) and Germany (5.0\%). As a result, in 2018 they accounted almost $63 \%$ of purchases Ukrainian meat products.

In geographical structure of the abroad supplying residues and waste of food industry, which totaled 5.7 million tons for 1.2 billion dollars, the dominant product is cake after sunflower processing. The largest volumes of purchases were made by Belarus $(12.7 \%)$, China $(11.6 \%)$, Turkey $(10.7 \%)$, France $(8.7 \%)$, Poland (8.6\%), the Netherlands (6.3\%), Spain (6.1\%), Morocco and Italy (both by $3.7 \%)$. Last year, these markets remained stable partners for Ukraine, creating the final share in exports at $72 \%$.

It is logical that our country, carrying out such sales of agrarian products in the global market, occupies leading positions in the rating of exporting certain goods $[6,7,10]$. In particular, we rank first in the world in exports of sunflower oil, the third place among the largest suppliers of cake after sunflower processing, rapeseed and shelled walnuts. In the top ten Ukraine is also in supply of corn, barley, wheat, concentrated apple juice, honey, dried leguminous vegetables, soybeans and wheat flour (Table 1). 
Table 1. Ukraine on the global agricultural market (2018)

\begin{tabular}{|l|l|l|}
\hline Product & Ranking & Export quantity, $\mathbf{1 0 0 0}$ tons \\
\hline Sunflower oil & 1 & 5585 \\
\hline Cake after sunflower processing & 3 & 4471 \\
\hline Rapeseed & 3 & 2441 \\
\hline Shelled walnuts & 3 & 31 \\
\hline Maize & 4 & 21434 \\
\hline Barley & 4 & 3597 \\
\hline Wheat & 5 & 16373 \\
\hline Concentrated apple juice & 5 & 65 \\
\hline Honey & 5 & 49 \\
\hline Dried leguminous vegetables & 6 & 655 \\
\hline Soybeans & 7 & 2241 \\
\hline Wheat flour & 7 & 305 \\
\hline
\end{tabular}

Ukraine's agrarian trade with the European Union, which is carried out in the framework of the functioning Free Trade Agreement (FTA), should be separately highlighted. Over the past year, the positive balance for Ukraine in agricultural trade amounted 3.6 billion dollars. The Netherlands, Poland, Spain, Germany, Italy and France, which accounted for about $73 \%$ of the total turnover, remained the most important partners in trade of agricultural products for Ukraine among the EU countries. Expansion of mutual trade with Belgium and Great Britain continued. The number of enterprises that have received permits to export their products, in particular livestock, to the EU countries is also increasing.

Commodity structure of the Ukrainian agricultural export in the European direction is identical to the general, as it is formed by grain, oilseeds, fats and oils, residues and wastes. In 2018, Ukraine completely closed duty-free quotas for supplying to EU wheat, maize, barley and flour, apple and grape juice, processed starch, malt and gluten, processed products of malt and starch, processed tomatoes, honey, butter and poultry meat. Exhausted and additional preferential quotas for honey, processed tomatoes, wheat and maize. In total, domestic companies exported about 40 commodity positions last year, but most of the quotas were not used even by half.

Positive trends in Ukrainian agrarian exports, which were underlined in the last year, have all the reasons to continue for at least in 2019. In particular, due to the largest grain harvest in Ukraine of 70.1 million tons in 2018, it is really to expect not only to fully meet the needs of domestic food market, but also to increase the sales figures on foreign markets. Taking into account the fact that stable high harvests, which exceeded 60 million tons in the past five years contributed to the assertion Ukraine among the leading players in the global grain market, current quantity of supply, according to most industry experts, will enable us to achieve export at the level about 50 million tons. In the interests of such a forecast there is an actual data of the current marketing year (July 2018 - June 2019), according to which at the end of March Ukraine has already sold more than 35 million tons of grain on the international market, including almost 19 million tons of maize, about 13 million tons of wheat and more than 3 million tons of barley. As in previous years, it has already been possible quite using several duty-free quotas for food supplies to the European Union. At the beginning of 2019 , volumes of honey, apple and grape juice, maize and sugar were selected. In addition, some of the basic quotas will increase according to the FTA conditions. Moreover, effect of the newly granted preferential quotas will continue. Thus, there are good prospects, at least for the export of agricultural products to Europe and Asia, which, by their demand, have a decisive influence on Ukraine's total agrarian export [8,9].

At the national level, efforts is ongoing to find new partner countries to create free trade zones. In this year an FTA with Israel was signed in January, negotiations on concluding similar agreements with Turkey and Serbia are underway. Each of these markets is in its own way attractive for domestic exporters of food products, and the achievement of final agreements will stimulate the intensification of mutual trade. 


\section{Conclusions}

Ukraine has firmly established itself as a leading supplier of agrarian products in the world market, as it has favorable natural and climatic conditions, excellent geographical location, traditional foreign markets and is increasingly adapting to the modern requirements of consumers in different regions of the planet. At present, the most share of revenues comes from domestic exporters of raw materials, and the finished food products account for a significantly smaller share in the commodity structure of foreign supplies. It is obvious that the export potential of our country in agro-food products is far from being exhausted. First of all, the reserve is to make full use of partnership with the European Union, especially with neighboring countries. Despite the existence of trade preferences, it leaves much to be desired exports to North America, in particular Canada and the United States, to study their consumer needs and to conquer the relevant segments it is needed more time for our entrepreneurs. It is worth to continue finding niches in the markets of high value added products, because they are less exposed to price fluctuations and usually characterized by smaller number of competitors. Achievement of the above goals, provided the stable economic situation in Ukraine, will contribute to a fuller disclosure of the opportunities in our agrarian sector both in terms of development of domestic production and commodity diversification of export supplies. In further research on this topic the most interesting is concentrating on finding niche markets for agricultural products that have a limited number of consumers and can purchase products that made in Ukraine.

\section{References}

1. Vlasov V.I. (2012). Globalistyka: istoriya, teoriya: monografiia u 2 t. [Globalistics: History, Theory: monograph: 2 vols.]. Vinnytsya: TOV «Nilan-LTD» [In Ukrainian].

2. Chlenstvo Ukrainy v SOT: ohliad zoboviazan ta komentari do nykh [Ukraines membership in the WTO: a review of commitments and comments]. Retrieved from: http://www.ier.com.ua/files/Books/ 16_Chlenstvo_v_SOT/16_book_2008_Guidebook_TIBA_ua.pdf [In Ukrainian].

3. Lupenko Yu.O., Pugachov M.I., Dukhnytskyi B.V., et al. (Lupenko Yu.O., Pugachov M.I. Eds.). (2015). Formuvannia hlobalnoho i rehionalnoho rynkiv silskohospodarskoi syrovyny ta prodovolstva: monohrafiia [Formation of global and regional markets for agricultural raw and food: monograph]. Kyiv: NNTs «IAE» [In Ukrainian].

4. Kvasha S.M., Vlasov V.I., Kryvenko N.V., et al. (Kvasha S.M. Ed.). (2013). Eksport ta import produktsii ahrarnoho sektoru Ukrainy: stan ta tendentsii [Export and import the products of agrarian sector of Ukraine: state and trends]. Kyiv: NNTs «IAE» [In Ukrainian].

5. Pugachov N. (2017). The Eurasian Wheat Belt and Food Security. Global and Regional Aspects. Springer International Publishing Switzerland. 180 p. [In English].

6. Artushin V., Kobets M., Pugachov M. (2011). Impacts of the Global Financial and Economic Crisis Upon the Agro-Food Sector of Ukraines Economy. Economics and Rural Development. 1, pp. 7-17. [In English].

7. Pugachov M. (2014). Agricultural reform: an impact assessment. Barometer of Change. 7, 28 p. [In English].

8. Bilorus O.G., Zubets M.V., Sabluk P.T., Vlasov V.I. (2009). Globalna prodovolcha bezpeka [Global food security]. Kyiv: NNTs IAE [In Ukrainian].

9. Kvasha S.M., Kvasha K.S. (2013). Stan ta tendentsii rozvytku silskoho hospodarstva krain-chleniv Yevropeiskoho Soiuzu [Status and trends of agricultural development in the European Union member states]. Kyiv: NNTs IAE [In Ukrainian].

10. Pugachov M.I., Dukhnytskyi B.V. (2017). Perspektyvy eksportu agroprodovolchoyi produkciyi Ukrainy: 20 osnovnyh krayin-importeriv kukurudzy [Agricultural export prospects of Ukraine: 20 main importing countries of maize]. Kyiv: NNTs IAE [In Ukrainian]. 